\title{
Quality of life index in Algerian environmental legislation
}

Mohamed BELFEDEL Faculty of Law, University of Tiaret, Algeria

Available online at https://www.maspolitiques.com/ojs/index.php/ajps/article/view/212

Email: mohamed.belfedel@univ-tiaret.dz

\section{Abstract:}

A new indicator is added to the indicators that countries seek to achieve by all means. He's the Quality of Life Index To determine the state's progress in balancing environmental resources with economic and human needs, Leading to good governance in order to achieve happiness and prosperity, environmental resources, and economic and human needs to reach good governance for happiness and well-being by adopting the standards of laws and conventions The quality of life index refers to the integration of people and other environmental elements on the one hand, and physical and psychological health and safety standards on the other side, It reflects a deep understanding of quality of life and environmental issues. In this research we will discuss the existence of this vital indicator in the field of environmental and urban legislation, where the rapid change supported by modern technologies and its impact on the quality of life in Algeria.

Keywords: quality of life, quality of life dimensions, quality of life indicators, sustainable development, Environmental Protection Law.

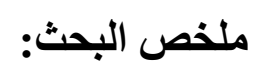

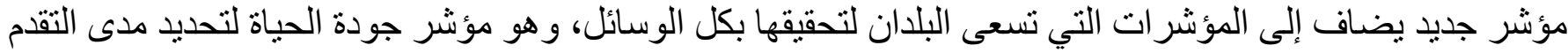

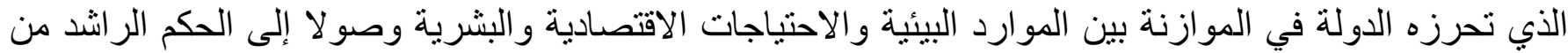

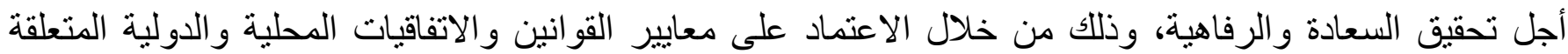

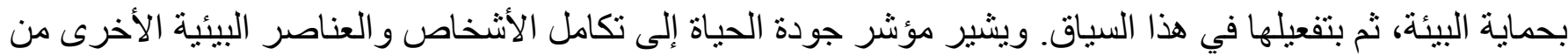

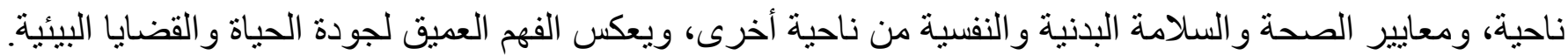

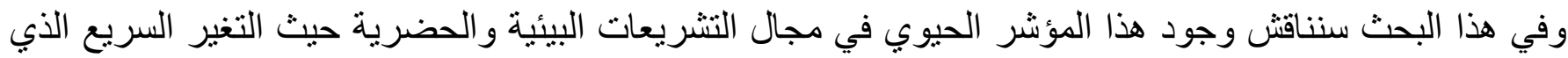
تدعمه التقنيات الحديثة وتأثيره على نو عية الحياة في الجز ائر.

الكلمات المفتاحية:جودة الحياة، أبعاد الجودة، مؤشرات الجودة، التتمية المستدامة، قانون حماية البيئة. 


\section{Search problem:}

The concept of quality of life is a broad and complex concept based on a number of indicators, through which the level of satisfaction with respect to the most important aspects of an individual's life is measured, but these indicators remain largely relative. The study examined one of these indicators in detail as a common indicator with other indicators. It is an environmental quality index.

This paper examines the environmental legislative texts bearing this indicator and explores the extent to which this mechanism has reached its impact on the quality of life Statute of the International and national laws. For this purpose, the paper is divided into three sections; The first part concerns the concept of quality of life, through an environmental legal approach. The second section discusses the extent to which environmental legislation is considered a measure of the quality of life. The third section deals with the means of achieving quality of life based on law enforcement. In conclusion, a summary and some recommendations are presented on how to overcome the legal obstacles that have been discussed to achieve the objective of environmental legislation.

\section{Introduction:}

The human being is in search of progress and good quality of life, this concept "quality of life" was reintroduced in the sixties of the 20th century in the United States of America and developed in France, It confirms that material progress alone is not enough to live well. Researchers have increased interest in the concept of quality of life as a satisfaction of the individual with his or her ability to live and feel complacent, has opportunities, expresses self-awareness, assesses the physical aspects of his or her life and the importance of each side to him or her at a given time and under certain circumstances. Clearly, in terms of happiness or misery, this affects the individual's daily interactions and interactions.

Quality of life on the human side requires the necessary connection between two elements: the existence of an organism and the existence of a good environment in which the organism lives. The natural environment, with its natural resources and the artificial 
environment that constitutes the individual's quality of life, and the social environment that governs the behavior of individuals and groups according to the norms of society, which refers to the self-evaluation of their living conditions, their sense of satisfaction, happiness and ability to satisfy their needs through the richness of the environment and the quality of the services provided to them in the fields of health, social, educational and psychological services with good time management and take advantage of it.

The environment reflects the social and economic system of one society at a time, but there is a gap between the concept of quality of life and the concept of living standards: the former focuses on the physical environment, physical and mental health, education, recreation and social identity, while the latter is based on income. In terms of quality of life, the highest percentages of available housing, available jobs, traffic, public education, environment, parks and recreation facilities.

Some countries are interested in this concept and have introduced it in the field of teaching, study and research, particularly in medical science studies, social sciences and humanities.

There are currently international centers and units specialized in research and study of quality of life, many partners of the body and sources of life improvement, through which the concept of life and quality, to add people to their homes and jobs and traffic, more social, cultural and environmental indicators. The forms presented in this document relate to the existence of this key indicator in the field of environmental legislation and its impact on the quality of life in Algeria, as indicated in the following points according to the analytical approach and methodology of the survey.

\section{CONCEPT OF QUALITY OF LIFE:}

The quality of life is a more factorial concept, it is synonymous with satisfaction, happiness and the capacity to satisfy one's needs thanks to the richness of the environment and the quality of the services provided in the fields of health, both social, educational and psychological, with good time management. $\left({ }^{1}\right)$

\footnotetext{
1 - the World Health Organization (1994, see WHOQOL Group) defines it as the "perception of an individual's place in life, in the context of the culture and value system in which he lives, in relation to its objectives, expectations, standards and concerns. This definition encompasses somatic state, physical
} 


\subsection{CONCEPT AND CONTENT OF QUALITY OF LIFE:}

The concept of quality of life has occupied humanity since antiquity under different names; its appearance was not new, but it was answered in Time. It is an extension of previous efforts. $\left({ }^{2}\right)$

The quality of life is one of the most important and fastest areas of scientific research and policy in the world. It is a measure of the well-being of individuals, peoples and societies. It contains several definitions based on a number of indicators, but it has almost been the subject of the WHO definition: "an individual's perception of his place in life, in the context of the culture and value system in which he lives, in relation to his objectives, expectations, norms and concerns".( $\left.{ }^{3}\right)$

Although the concept of quality mainly concerns physical and technological aspects, it can be used to describe human structure, function and sensitivity. The result is quality of life and quality of society, which contribute significantly to quality of life. Social justice, planning and sustainable development addressing risks, housing, infrastructure, basic services, climate change and environmental sustainability. Urban legislation, governance and economy are linked to the environment and quality of life.

The rights set out in the concept of quality of life constitute a coherent system of intrinsically coherent components, on the one hand, and the possibility of sacrificing for each other. The basic assumption is that the rights and freedoms at stake are elements of the concept of quality of life, in the sense that they are the criteria for judging quality of life over time and in place.

The term quality of life means happiness and satisfaction with life, but what the studies dealing with this term retain is that it does not fully indicate the missing definition of legal practitioners which focuses on the most important elements for which the right has

autonomy, psychological state, psychological functioning, well-being, social interactions, professional activities and economic resources.

2 -Wolfgang Glatzer :challenges for Quality of life in the11contemporary world, Springer, New York, 2004, pp. 21-22

3 -world Health Organization, «Measuring Quality of life» p.4.

www.who.int/mental-health/media/68pdf 
existence and continuity that guarantee an adequate or known standard of living. In addition to human dignity, which are legal interests protected by law as distinct rights.

Thus, the term quality of life does not exist in the various national and international laws, it is implicitly guaranteed as being achieved by the enjoyment of one of its fundamental rights, so that the same legal provisions guaranteeing these rights are in themselves a guarantee of the quality of life.

And the concept of quality of life derived from emerging theoretical and practical concepts, while being difficult to identify its links with many aspects of life, makes this concept a national trend of communities and an objective of achieving all political, economic and social systems. Its commitment to the most important human rights, namely the right to life, to preserve and improve its quality and to preserve its dignity and to improve the level of social, economic, health and environmental services, with the aim of improving people's lives by improving living conditions by meeting the various material needs of human survival.

The inventory of concepts and contents of quality of life and the proposal for an integrated strategy for sustainable development aim to ensure a balance between the social, cultural, economic and environmental dimensions. This requires the creation of a database on quality of life, a functional database to identify the role, functions and responsibilities of all parties involved, in particular the monitoring of the development of quality indicators for cities in accordance with established evaluation criteria.

\subsection{LEGAL APPROACH TO QUALITY OF LIFE:}

The concept of quality of life is one of the most important concepts that has occupied humanity since antiquity, rooted in the ancient philosophy that it addressed in the concept of virtuous living, happiness, well-being and pleasure. Among the positive concepts advocated by many philosophers from antiquity to the modern times. $\left(^{4}\right)$

The concept of quality of life has received particular attention from researchers, whether economic, political, social, even psychological or health, which has led to a multiplicity of indications and different definitions. Most definitions focus on two aspects:

\footnotetext{
4 - Alain Le plège, Mesure de la santé perceptuelle et de la qualité de vie : méthodes et applications, Paris, ESTEM, 2001, p 333 .
} 
an objective aspect based on the achievement of various social needs and services and a subjective aspect based on the self-assessment of each individual's life. The concept of quality of life has often been closely linked to the concepts of well-being, dignity, satisfaction of needs and improvement of living standards, which seem to express quality of life more than social processes. $\left({ }^{5}\right)$

The most important definitions of "quality of life" in the light of previous studies are in line with the idea of the intrinsic value of each person's life, which varies according to their assessment from one person to another, which has made this concept the subject of case law and controversy.

The approach adopted in this research is legal and based on the introduction of the concept of "quality of life" as a human right and as researchers in the legal field. It has focused on the human right to quality of life as an extension of the right to life and has not yet defined this right. Quality of life has not been treated legally or separately, it has been mentioned as a broad concept that is not limited to the material aspect, but also includes the human dignity of each individual and reflects the desires and needs that make the individual happy and satisfied with his life.$\left(^{6}\right)$

\subsection{LEGAL BASIS AND LEGAL BASIS FOR QUALITY OF LIFE:}

It should be mentioned that human efforts to obtain a constitutional basis for the enjoyment of all human rights and freedoms have been difficult, as have many English, French and American revolutions, which have had a considerable impact on the emergence of advertising and rights and freedoms. Article 25/1 of the Universal Declaration of Human Rights provides:"Everyone has the right to a standard of living adequate for the

\footnotetext{
5 - La qualité de vie d'une population est un enjeu majeur en sciences économiques et en science politique. On utilise les notions proches d'utilité et de bien-être. Elle est mesurée par de nombreux indicateurs socio-économiques (l'indice de développement humain (IDH) par exemple). Elle dépend dans une large partie de la capacité à acheter des biens et services (notion de pouvoir d'achat), mais aussi des situations dans les domaines de la liberté (libéralisme économique), de respect des droits de l'homme, de bonheur, de santé, etc.
}

${ }^{6}$--- www.arab-api.org/imades/publication/pdfs/115/115-develop-bridge2.pdf Vu le 8/7/2018. 
health and well-being of himself and of his family, including food, clothing, housing, medical care and necessary social services; he is entitled to security in the event of unemployment, sickness, disability, widowhood, old age or other lack of livelihood in circumstances beyond his control...."

The constitutional recognition of the human rights included in it, especially since most constitutions broaden the scope of recognition from the right to life to the right to physical existence of the human being, and encompass the rights resulting from this right such as the continuity of the life of individuals. The recognition of this right is intended to ensure the safety of the body and respect for, and not to harm, human personality and dignity, as they stem from the nakedness of man, regardless of his status. The constitutions also recognized the economic and social rights necessary to enjoy an adequate standard of living, on the environment which is the basis for a better life. $\left({ }^{7}\right)$

These principles and rights are in themselves essential dimensions of quality of life, but the recognition of quality of life in the Constitution does not provide sufficient protection and guarantee for this right or fundamental protection against violations, unless effective guarantees reinforce it by setting out the principles of democracy such as the rule of law, justice, the establishment of various systems of security and protection of persons against various threats to their right to quality of life and the development of their potential in order to help them participate and contribute to a better life. $\left({ }^{8}\right)$

The mechanisms enshrined in the constitutional legal foundations of the right to quality of life are determined by national mechanisms for the protection of human rights, which concern the bodies, institutions, organs and departments responsible for monitoring and evaluating the performance of the executive in the application of laws and compliance with international standards on the rights and freedoms of individuals.

\footnotetext{
7 - La Convention relative aux droits de l'enfant (aussi appelée Convention internationale des droits de l'enfant) adoptée en 1989 par l'assemblée générale des Nations Unies prohibe la peine de mort pour les enfants et dispose en particulier dans son article 6 que « Les États parties reconnaissent que tout enfant a un droit inhérent à la vie. »

8 - The Universal Declaration of Human Rights, adopted by the United Nations General Assembly on December 10, 1948.
} 
The mechanisms enshrined in the constitutional legal foundations of the right to quality of life are determined by national mechanisms for the protection of human rights, which concern the bodies, institutions, organs and departments responsible for monitoring and evaluating the performance of the executive in the application of laws and compliance with international standards on the rights and freedoms of individuals.

\subsection{ENVIRONMENTAL LEGISLATION MEASURES QUALITY OF LIFE:}

Environmental law is a law that deals with the environment in order to preserve and protect it. $\left({ }^{9}\right)$ It is published in the form of a legal text. According to the modern concept, it concerns not only the natural environment and its components, but also the human environment, such as the sanitary, social and other conditions created by man and affecting his survival on the ground, thus focusing on man and his impact on the natural and industrial external environment. The World Health Organization (WHO) agreed to collaborate on a large scale on 10 January 2018 on environmental health risks to accelerate action to reduce environmental health risks, which cause an estimated 12.6 million deaths per year.$\left({ }^{10}\right)$

\footnotetext{
9 - la loi $\mathrm{n}^{\circ}$ 03-10 du 19 juillet 2003 relative à la protection de l'environnement dans le cadre du développement durable. joradp $\mathrm{n}^{\circ} 43$ du 20 juillet 2003. loi nº $02-02$ du 5 février 2002 relative à la protection et à la valorisation du littoral, joradp $\mathrm{n}^{\circ} 10 \mathrm{du} 12$ février 2002. loi n ${ }^{\circ}$ 04-20 du 25 décembre 2004 relative à la prévention des risques majeurs et à la gestion des catastrophes dans le cadre du développement durable. joradpn ${ }^{\circ} 84$ du 29 décembre 2004. loi nº 04-03 du 23 juin 2004 relative à la protection des zones de montagnes dans le cadre du développement durable. joradp n ${ }^{\circ} 41$ du 27 juin 2004 et la Loi ${ }^{\circ}$ 10-02 portant approbation du Schéma National d'Aménagement du Territoire. Loi n 07-06 relative à la gestion à la protection et au développement des espaces verts Loi $\mathrm{n}^{\circ}$ 06-06 portant loi d'orientation de la ville .Loi ${ }^{\circ}$ 04-09 relative à la promotion des énergies renouvelables dans le cadre du développement durable. Loi ${ }^{\circ}$ 04-03 relative à la protection des zones de montagnes dans le cadre du développement durable. Loi ${ }^{\circ}$ 03-10 relative à la protection de l'environnement dans le cadre du développement durable .Loi ${ }^{\circ}$ 02-08 relative aux conditions de création des villes nouvelles et de leur aménagement .Loi ${ }^{\circ}$ 01-20 relative à l'aménagement et au développement durable du territoire .Loi $\mathrm{n}^{\circ}$ 01-19 relative à la gestion au contrôle et à l'élimination des déchets ....... Etc. et leurs textes exécutif ${ }^{10}$-http://www.who.int/ar/news-room/detail/23-04-1439-un-environment-and-who-agree-to-majorcollaboration-on-environmental-health-risks
} 
Environmental indicators of quality of life: reducing pollution and preserving the environment, in particular due to many phenomena that threaten health and life in general, such as global warming and the use of ozone-depleting substances and products containing chlorofluorocarbons and quality of life indicators. An environmental security measure that means the release of nature and human beings from various environmental risks that have negative effects on the safety and lives of people. Thus, environmental security allows every human being to enjoy the right to a healthy and clean environment, which is the fundamental instrument of human rights. $\left({ }^{11}\right)$

Environmental indicators and reports are one of the most important tools to help decision-makers plan their activities effectively in order to determine priorities for the exploitation of available resources and to achieve desired objectives.

The performance of environmental indicators and reports accurately reflects the environmental situation in the implementation of policy guidelines for taking all environmental conservation measures. In order to guarantee a safe and healthy life for citizens wishing to progress towards sustainable development. Thus, quality of life is measured by a set of indicators that can be summarized as follows:

1. Ensure the safety of food, water and air.

2. Elimination of indiscriminate construction.

3. Reform of the road network and transport.

4. Prevention of wastewater pollution.

5. Waste treatment.

6. Combating desertification. $\left({ }^{12}\right)$

\subsection{EFFECTS OF POLLUTION ON QUALITY OF LIFE:}

Pollution is defined as a direct or indirect release resulting from human activity, represented by substances, vapors, heat and noise in the atmosphere, water and soil, that may harm human health and the quality of the environment, leading to the destruction and deterioration of physical properties and legitimate uses of the environment. It is also

\footnotetext{
11 - P.H.Liotta (el):"Environmental change and human security "Springer, New York, 2007, p223.

12 -Joelle Le Moal, Daniel Eilstein et Georges Salines: La santé environnementale est-elle l'avenir de la santé publique ? Dans Santé Publique 2010/3 (Vol. 22), pages 281 à 289
} 
known as physical and chemical changes in the natural elements and changes in their properties. $\left({ }^{13}\right)$

A- Natural sources of pollution: Which have no human contribution, such as rising ground gases, volcanoes, forest fires and dust. These sources are generally limited to minor damage. $\left({ }^{14}\right)$

B- Unusual sources of pollution: The human being is the most dangerous and worrying and whose components have become multiple and varied, causing an imbalance in the environment, especially after the progress of science and technology, increasing the needs of life. The use of chemical fertilizers and pesticides of all kinds, all of which are effective in disrupting the balance of ecosystems, ultimately affect human life without affecting its quality.

In paragraph 6 of the Declaration of the United Nations Conference on the Human Environment, Stockholm, 1972: "We have reached a historic point in which we must shape our actions in the world with the greatest concern for their consequences on the environment. On the contrary, with the greatest knowledge and wisdom of work, we can achieve a better life for ourselves and our offspring in a more humane environment and hope. The preservation and improvement of the human environment for present and future generations has become an objective. There is no way for the sons of humanity to be only reached". $\left({ }^{15}\right)$

Since the Industrial Revolution, the world has been affected by pollution, which has caused global warming, changed the geography of the earth and hidden many natural elements such as forests and glaciers, causing the extinction of many organisms, as well as

13 -- Former M, Managing Environmental pollution St California, USA, 1999, p54.

14 -- Porter M. \& Lind Claas Vaner, "Green and Competitive Ending the Stalemate, Harvard Business Review, Sep-Oct, 1995, p 120

15 - paragraphe 6 de la préambule de la déclaration de la Conférence de Stockholm sur l'environnement humain, 1972 
the technological and industrial development of many large countries. Measures to reduce pollution, particularly in recent decades, since the 1972 Stockholm Conference. $\left({ }^{16}\right)$

The environmental situation in Algeria is characterized by deterioration and apathy. Significant sand creep and low cover, which are shrinking due to drought, cement creep and tree planting policy, which was a previous priority and the alphabet of volunteerism until the late Seventies of the twentieth century. The polluted marine environment, degraded beaches and industrial pollution. On the other hand, demographic pressure and urban problems are detrimental to living conditions...

Faced with the significant loss that society pays as a tax on environmental corruption, whether it is the costs of treating diseases caused by a polluted environment, or the natural resources wasted daily and which require a lot of money to be repaired. The role of law, which must be present in all aspects of life. In its relationship with the environment and its use, the environmental balance must be preserved from any imbalance. Algeria has a legal arsenal linked to environmental protection, which needs to be further activated on the ground, highlighting the existence of another legislative vacuum in the field of environmental crime. $\left({ }^{17}\right)$

\subsection{QUALITY OF LIFE AND COMMUNITY RANKING:}

The 2011 annual indicator showed the best countries in the world where Algeria ranked 139th out of 192 countries included in the study Algeria, according to the report published by the magazine "International Living" on its website from 146 to 139. This indicator, which included nine sub-components reflecting the economic and social standard of living.

The American Journal of Quality of Life measures the cost of living and leisure index in nine main indicators, followed by culture, economic growth, freedoms, public health,

\footnotetext{
16 - La conférence de Stockholm de 1972 était une étape importante et sa déclaration finale comprenait 26 principes qui représentent une écologie de cette époque. En répondant à la nécessité "d'inspirer et de guider les peuples du monde afin de préserver et d'améliorer l'environnement humain", la Déclaration a jeté les bases du nouveau programme environnemental adopté par le système des Nations Unies ${ }^{17}$ - Marc Pallemaerts: Le cadre international et européen des politiques de lutte contre les changements climatiques Dans Courrier hebdomadaire du CRISP 2004/33-34 ( $\left.{ }^{\circ} 1858-1859\right)$, pages 5 et suite..
} 
infrastructure, risk and safety, public health, quality of life and safety of life. In order to advise American retirees and help them determine the standard of living and destinations of their choice around the world, through the lists of the rich, the world's universities, unemployment, divorce, adulthood, suicide, smiling and others, the news is not new in the understanding of peoples in the quality of life and reported by the agency "American in Arabic" and published by the institution (International Living).

France ranked first in the world, followed by Australia, the Netherlands and New Zealand, while the United States ranked fifth in terms of quality of life. As Algeria emerged from the ranking, published by the Institute "Inter nations" year 2015". The report selected 64 countries out of 195 countries. The index is based on several criteria, including leisure time, personal happiness, ability to travel easily, health, safety and well-being, as well as several indicators published in a 234-page in-depth study. In 2017, Algeria ranked 116th out of 149 countries on the boom index, based on the same indicators. $\left({ }^{18}\right)$

\section{ENVIRONMENTAL MANAGEMENT IN THE CONTEXT OF DEVELOPMENT DIRECTION} AND ITS ROLE IN QUALITY OF LIFE:

As the human dimension of sustainable development is inherent in the environmental dimension underlying the continuity of life, it is the responsibility of current generations to preserve natural resources for future generations. Policies and procedures that take into account the balance between the construction of natural resources and the destruction of human beings within a given time frame can only be achieved through responsible natural resource management that meets the needs of present and future generations.

Environmental management is defined as "the management of human activities that have significant impacts on the environment and that are designed to meet basic human

18 -- the legatum prosperity index ${ }^{\mathrm{TM}} 2017$ creating the pathways from poverty to prosperity. https ://www. prosperity. com/ globe/algeria 
needs within the framework of natural resources, thus enabling long-term development on a continuous basis". $\left({ }^{19}\right)$

Environmental management is the development of plans and policies for environmental impact monitoring and assessment to avoid many environmental problems that threaten the quality and sustainability of human life. Environmental management implies that environmental resources are not used in such a way as to create an environmental debt that threatens the lives of future generations. Strategies that respect the natural environment as much as possible by adopting economic production methods that respect the environment, that aim to improve the quality of life by avoiding increasing pressure on the planet's potential.

Environmental management aims to provide individual skills that enable it to understand the relationship between itself and its natural environment and thus make informed decisions about environmental issues that affect the quality of life and compromise the chances of sustainability for future generations. It thus shows the importance for the current generation to take into account the needs of future generations, not to pollute their vital systems, thus limiting human well-being and the chances of survival. $\left({ }^{20}\right)$

3.1: QUALITY OF LIFE DEPENDENT ON LAW ENFORCEMENT: The enforcement of all environmental or environmental laws can change the living reality, particularly with regard to the beauty of the ocean to achieve desired development, and thus desired social wellbeing, and the trade-off in environmental protection depends on the extent to which exploitation, resources and diverse energies are rationalized.

Algerian laws are very good; the clean environment maintains public health and life in general. The causes of environmental and environmental degradation are known. The

\footnotetext{
19 - Gisèle Belem, « Le développement durable en Afrique : un processus sous contraintes Expérience de l'industrie minière malienne », VertigO - la revue électronique en sciences de l'environnement [En ligne], Volume 7 Numéro 2 | septembre 2006, mis en ligne le 27 avril 2006, consulté le 26 février 2019. URL : http:// journals .openedition .org/ vertigo /2242 ; DOI : 10.4000/vertigo.2242

20 -idem.
} 
human factor is sufficient to eliminate the legal vacuum in the application of all environmental laws in order to see the results.

Preserving the environment improves the reality of individuals and communities and allows the individual to lead a balanced life even if his or her standard of living is simple, thanks to a sense of social stability.

All environmental efforts, including Law 19/01 on waste management, assessment and treatment, as well as the urban planning plan. Criminal provisions or fines applicable to offenders. Polluters between 5,000 and 10,000 dinars and may reach the prison in force in case of recidivism, or even in the event of sand looting or ecological damage, all exist and are protected by laws, but they remain on paper.

A- Role of associations: The role of associations can be mentioned here, and we affirm that it could be entitled to bring civil action in such cases and request material compensation for environmental activities with a societal dimension, but there are no such cases. The environmental violation is limited to violations committed by the urban planning police, i.e. simple statistics in the absence of thorough investigations and the arrest and prosecution of the aggressors. $\left({ }^{21}\right)$

21 - Chapitre 6: De l'intervention des individus et des associations en matière de protection de l'environnement:

Art. 35. Les associations légalement constituées et exerçant leurs activités dans le domaine de la protection de l'environnement et de l'amélioration du cadre de vie, sont appelées à contribuer, à être consultées et à participer à l'action des organismes publics concernant l'environnement conformément à la législation en vigueur.

Art. 36. Sans préjudice des dispositions légales en vigueur, les associations visées à l'article 35 ci-dessus sont habilitées à agir devant les juridictions compétentes pour toute atteinte à l'environnement même pour des cas ne concernant pas leurs membres régulièrement affiliés.

Art. 37. Les associations légalement agréées peuvent exercer les droits reconnus à la partie civile en ce qui concerne les faits portant un préjudice direct ou indirect aux intérêts collectifs qu'elles ont pour objet de défendre et constituant une infraction aux dispositions législatives relatives à la protection de l'environnement, à l'amélioration du cadre de vie, à la protection de l'eau, de l'air et de l'atmosphère, des sols et sous-sols, des espaces naturels, à l'urbanisme ou ayant pour objet la lutte contre les pollutions. 
The activation of existing laws is a realistic solution and one of the most important principles of the 03/10 law on the protection of the environment in the context of sustainable development and the establishment of the information principle.

This means that environmental protection associations should be informed on various issues that may arise in the field of environmental protection, to claim compensation in a special fund to finance these associations of defense of the environment. environment, that is the protection of society against diseases and epidemics, and even the achievement of social stability in terms of protection of the environmental resources of water resources against pollution due to the growing urban and industrial fabric. Which also has a positive impact on the quality of life. $\left({ }^{22}\right)$

Art. 38. Lorsque des personnes physiques ont subi des préjudices individuels qui ont été causés par le fait d'une même personne et qui ont une origine commune, dans les domaines mentionnés à l'article 37 cidessus, toute association agréée au titre de l'article 35 ci-dessus peut, si elle a été mandatée par au moins deux (2) des personnes physiques concernées, agir en réparation devant toute juridiction au nom de cellesci. Le mandat doit être donné par écrit par chaque personne concernée. L'association qui exerce une action en justice en application des alinéas précédents peut exercer devant toute juridiction pénale les droits reconnus à la partie civile.

22 - Article 4 de la loi 03/10: Au sens de la présente loi on entend par:

Aire protégée: Une zone spécialement consacrée à la préservation de la diversité biologique et des ressources naturelles qui y sont associées.

Espace naturel: Tout territoire ou portion de territoire particularisé en raison de ses caractéristiques environnementales. Les espaces naturels incluent notamment les monuments naturels, les paysages et les sites.

Biotope: Une aire géographique où l'ensemble des facteurs physiques et chimiques de l'environnement restent sensiblement constants.

Développement durable: Un concept qui vise la conciliation entre le développement socio-économique permanent et la protection de l'environnement, c'est à dire l'intégration de la dimension environnementale dans un développement qui vise à satisfaire les besoins des générations présentes et futures.

Diversité biologique: La variabilité des organismes vivants de toute origine y compris, entre autres, les écosystèmes terrestres, marins et autres écosystèmes aquatiques et les complexes écologiques dont ils font partie; cela comprend la diversité au sein des espèces et entre espèces ainsi que celle des écosystèmes.

Écosystème: Le complexe dynamique formé de communautés de plantes, d'animaux, de micro- 
B - Role of the citizen: The participation of citizens in environmental decisions, as required by the application. Environmental responsibility must be involved in various projects at the local level, including the preparation of the urban planning scheme, raising awareness of the importance of environmental issues. The fact that its future depends on the extent to which it is maintained and that the environmental dimension is not limited to collective work or the ministry of the sector. However, this is a shared responsibility, each in its own field; for example, the housing sector is concerned about the environment by allocating green spaces and increasing the number of spaces to educate the population of the highest importance to be given to environmental preservation in new population plans, as well as for the sector. Forest interests by increasing awareness of forest conservation as a fundamental source of life and other activities by sector, as the environment is a societal issue as a whole and cannot be separated from one sector to another. By activating all this, the quality of our lives will change for the better.

organismes et de leur environnement non vivant, qui par leurs interactions forment une unité fonctionnelle.

Environnement: Les ressources naturelles abiotiques et biotiques telles que l'air, l'atmosphère, l'eau, le sol et le sous- sol, la faune et la flore y compris le patrimoine génétique, les interactions entre lesdites ressources ainsi que les sites, les paysages et les monuments naturels.

Pollution: Toute modification directe ou indirecte de l'environnement provoquée par tout acte qui provoque ou qui risque de provoquer une situation préjudiciable pour la santé, la sécurité, le bien-être de l'homme, 1a flore, la faune, l'air, l'atmosphère, les eaux, les sols et les biens collectifs et individuels. Pollution des eaux: L'introduction dans le milieu aquatique de toute substance susceptible de modifier les caractéristiques physiques, chimiques et/ou biologiques de l'eau et de créer des risques pour la santé de l'homme, de nuire à la faune et à la flore terrestres et aquatiques, de porter atteinte à l'agrément des sites ou de gêner toute autre utilisation normale des eaux.

Pollution de l'atmosphère: L'introduction de toute substance dans l'air ou l'atmosphère provoquée par l'émanation de gaz, de vapeurs, de fumées ou de particules liquides ou solides susceptible de porter préjudice ou de créer des risques au cadre de vie.

Site: Une portion de territoire particularisée par sa situation géographique et/ou son histoire. 
The legislator has recognized the importance of a clean and balanced environment for human life, namely a person who does not suffer from communicable diseases or who may result from environmental problems.

Article 15 of the Constitution states: (A balanced environment is an objective that the State seeks to achieve and the preservation of the environment is the responsibility of the State and society. Under the law.

- The State has paid great attention to the environment and has promulgated Law No. 03/10 on the Environment in the Context of Sustainable Development, with the aim of:

1. Protect the environment from pollution in all its forms.

2. Protection of public health and well-being.

3. Introduce the foundations of environmental protection into economic and social development plans and promote sustainable development.

4. Encourage the collection and dissemination of various environmental information

Increase public awareness of environmental issues.

In preparing the program, it was based on fundamental pillars that support infrastructure and lifestyle improvements and others that achieve the desired goal:

- Develop solid infrastructure in cities.

- Provide comprehensive services to the population to meet their basic needs.

- Provide a social framework that can interact with citizens and residents.

- Develop a global living infrastructure.

- Provide a variety of quality of life options.

- Motivate people to interact and ensure their participation through activities and events specific to the lifestyle and society.

Determine the regulatory framework necessary to enable quality of life in all categories.

- Create financing mechanisms, including public-private partnership models, incentives and public investments to facilitate private sector participation.

- Communicate with all stakeholders (citizens, private sector, etc.) to present the progress of the program in all its aspects. 


\subsection{ENSURING THE SUSTAINABILITY OF ENVIRONMENTAL QUALITY OF LIFE:}

The relationship between the environment and human life is eternal.

Since the environment cannot be considered neutral, contemporary environmental discourse attempts to prove that quality of life will not be achieved through policies that neglect it. To ensure the sustainability of the quality of life, it is essential to ensure environmental sustainability, which can only be achieved by meeting the demand for a healthy environment that is not simply a natural element, but a balance of material and economic resources available to meet human needs across the time domain. Environmental sustainability therefore considers it unfair to live one generation at the expense of other generations. $\left({ }^{23}\right)$ It is the same idea of sustainable development that aims at intergenerational justice.

Environmental indicators are an important tool for identifying, analyzing and assessing environmental problems, as well as for monitoring the state of the environment over time. It is an important means of monitoring policy performance and measuring the improvement in the achievement of individual objectives in a better life, as environmental indicators aim to ensure the economic well-being of current and future generations by protecting the environment from various risks and enabling them to improve economic and social life. Tires environmental indicators on the quality of the environment in terms of air, water for agriculture and living spaces, as well as the assessment of environmental pollution levels and the impacts of climate change on people's lives.

This shows the most important objective indicators that can be expressed qualitatively and measured quantitatively and self-assessed, expressing people's satisfaction with their level and quality of life in the following areas:

1. Water quality.

2. Soil quality.

\footnotetext{
${ }^{23}$-Bruno Boidin, «Développement humain, développement durable et «pays en développement »: comment articuler et mesurer les différentes dimensions ?», Développement durable et territoires [En ligne], Dossier 3 | 2004, mis en ligne le 01 février 2004,

URL :http://journals.openedition.org/developpementdurable/1120 ;DOI :10.4000/développement durable.1120. consulté le 27 février 2019.
} 
3. Climate index.

4. Health and environmental safety.

5. Free from need and make sure to preserve it.

There is a need to strengthen international environmental governance to ensure the implementation of international agreements to address environmental issues. $\left({ }^{24}\right)$

Finally, through the previous analysis, we show that human security seeks to proactively protect against all risks and threats to people's lives and well-being, thus focusing on creating an environment conducive to the quality of life and then interacting with human development. Individuals to enable them to seek a better quality of life.

\section{CONCLUSION:}

1. Quality of life is an individual and societal issue, although the notion of concepts has been addressed in different sciences and contexts, and to assess the level of quality of life as dimensions of survival, well-being and human dignity and the role of the State in legalizing quality of life. A subjective question, felt by all, which is part of the objective conditions that guarantee a decent life through the necessities of survival, material well-being that facilitate and guarantee human dignity, which makes quality of life a distinct, flexible and mobile concept corresponding to the perception of each person, which has made it a point of discussion, questions and differences all the more so since the study has included in many fields and disciplines. Most of the definitions discussed are based on religious, cultural and value backgrounds.

2. Quality of life indicators are important because they measure the extent of their actual survey and are not general and comprehensive standards for aspects of good and healthy living, but they are important aspects of them.

3. Quality of life can only be achieved in an environment that guarantees this. Ensure that the basic needs of individuals are met. It is necessary to develop an integrated strategy to improve the living, economic and social conditions of each individual, taking into account that natural, cultural and social resources are the right of all generations, within the framework of the obligation of social, legal and moral duty. Guarantee everyone

24 - Docs. de l'OCDE, « Perspectives de l'environnement de l'OCDE à l'horizon de 2030 », 2008. 
the right to improve their standard of living, as well as the preservation of the natural environment, which is an essential foundation for the sustainability of human life.

4. Therefore, legislation should be developed to improve the quality of life, take into account social integration and the different characteristics of the population. The needs of people with special needs to improve the quality of life and create flexible solutions and guidelines to address the challenges of poverty in different regions, in particular the reform of economic systems and institutional frameworks. Emphasize community participation and human resource development, especially for women and youth. Focus on the development of integrated environmental and development strategies aimed at promoting social integration, reducing poverty gaps in societies and periodically updating national urban policies and strategies, in coordination with relevant actors, with a view to integrating new policies that reflect changing development priorities and conditions. Justice in the distribution of investments to achieve a balance between the rural and urban sectors, in particular secondary and marginal communities, in order to maximize their role in promising new development areas, and stress the importance of the role of centers for the prevention of earthquakes and other natural disasters that have developed a risk management strategy and strategic plans to address them. Finally, strategic plans should be developed to address all natural disasters in order of priority, preparing an integrated environmental strategy to take full advantage of all forms of permanent and renewable energy, raising awareness of the importance of integrating the environmental system. Focus on the development of housing and urban indicators through the establishment and activation of the role of urban observatories in order to enable quality of life. 


\section{References:}

1- l'Organisation Mondiale de la Santé (1994, voir WHOQOL Group)

2- Wolfgang Glatzer :challenges for Quality of life in the11 contemporary world, Springer, New York, 2004.

3- world Health Organization, «Measuring Quality of life». www.who.int/ mental-health/media/68pdf

4- Alain Le plège, Mesure de la santé perceptuelle et de la qualité de vie : méthodes et applications, Paris, ESTEM, 2001.

5- www.arab-api.org/imades/publication/pdfs/115/115-develop-bridge2.pdf Vu le 8/7/2018.

6- The Convention on the Rights of the Child (also known as the International Convention on the Rights of the Child) adopted in 1989 by the United Nations General Assembly

7- The Universal Declaration of Human Rights, adopted by the United Nations General Assembly on December 10, 1948.

8- la loi n 03-10 du 19 juillet 2003 relative à la protection de l'environnement dans le cadre du développement durable. joradp $n^{\circ} 43$ du 20 juillet 2003.

loi $\mathrm{n}^{\circ}$ 02-02 du 5 février 2002 relative à la protection et à la valorisation du littoral, joradp $\mathrm{n}^{\circ} 10 \mathrm{du} 12$ février 2002. loi n 04-20 du 25 décembre 2004 relative à la prévention des risques majeurs et à la gestion des catastrophes dans le cadre du développement durable. joradpn ${ }^{\circ} 84$ du 29 décembre 2004. loi n $04-03$ du 23 juin 2004 relative à la protection des zones de montagnes dans le cadre du développement durable. joradp $n^{\circ} 41$ du 27 juin 2004 et la Loi n 10-02 portant approbation du Schéma National d'Aménagement du Territoire. Loi $\mathrm{n}^{\circ}$ 07-06 relative à la gestion à la protection et au développement des espaces verts Loi $\mathrm{n}^{\circ}$ 06-06 portant loi d'orientation de la ville .Loi $\mathrm{n}^{\circ}$ 04-09 relative à la promotion des énergies renouvelables dans le cadre du développement durable .Loi $\mathrm{n}^{\circ}$ 04-03 relative à la protection des zones de montagnes dans le cadre du développement durable .Loi $\mathrm{n}^{\circ}$ 03-10 relative à la protection de l'environnement dans le cadre du développement durable .Loi $\mathrm{n}^{\circ}$ 02-08 relative aux conditions de création des villes nouvelles et de leur aménagement .Loi n 01-20 relative à l'aménagement et au développement durable du territoire. Loi ${ }^{\circ}$ 01-19 relative à la gestion au contrôle et à l'élimination des déchets Etc. et leurs textes exécutif.

9- http://www.who.int/ar/news-room/detail/23-04-1439-un-environment-and-who-agree-to-majorcollaboration-on-environmental-health-risks

10- P.H.Liotta (el):"Environmental change and human security "Springer, New York, 2007. 
11- Joelle Le Moal, Daniel Eilstein et Georges Salines: La santé environnementale est-elle l'avenir de la santé publique ? Dans Santé Publique 2010/3 (Vol. 22)

12- Former M, Managing Environmental pollution St California, USA, 1999.

13- Porter M. \& Lind Claas Vaner, "Green and Competitive Ending the Stalemate, Harvard Business Review, Sep-Oct, 1995.

14- la Conférence de Stockholm sur l'environnement humain, 1972

15- Marc Pallemaerts: Le cadre international et européen des politiques de lutte contre les changements climatiques Dans Courrier hebdomadaire du CRISP 2004/33-34 (n 1858-1859).

16- the legatum prosperity index ${ }^{\mathrm{TM}} 2017$ creating the pathways from poverty to prosperity https ://www. prosperity. com/ globe/algeria.

17- Gisèle Belem, «Le développement durable en Afrique : un processus sous contraintes Expérience de l'industrie minière malienne », VertigO - la revue électronique en sciences de l'environnement [En ligne], Volume 7 Numéro 2 / septembre 2006, mis en ligne le 27 avril 2006, consulté le 26 février 2019. URL : http:// journals .openedition .org/ vertigo /2242 ; DOI : 10.4000/vertigo.2242.

18- Bruno Boidin, « Développement humain, développement durable et « pays en développement » : comment articuler et mesurer les différentes dimensions ? », Développement durable et territoires .. Dossier En ligne. 2004, mis en ligne le 01 février 2004, consulté le 27 février 2019. URL : http://journals.openedition.org/developpementdurable/1120 ;DOI :10.4000/développement durable.1120. 19- Docs. de l'OCDE, « Perspectives de l'environnement de l'OCDE à l'horizon de 2030 », 2008. 